\title{
The Use of Mother Tongue in Foreign Language Teaching from Teachers' Practice and Perspective
}

\author{
M. Naci Kayaoğlu*
}

\begin{abstract}
There has been a longstanding debate over whether the use of mother tongue in EFL classes should be avoided or welcomed. To what extent the use of $L 1$ facilitates $L 2$ learning or poses a debilitating effect on learners has been a perennial issue in second language learning. In spite of a lack of substantial empirical evidence favoring or hindering the use of mother tongue, some avoid using $\mathrm{L} 1$ (mother tongue) in foreign language classes due to the popular belief that the role of $L 1$ in SLA gets in the way of or interferes with the learning of $\mathrm{L} 2$, while others take a different position for various reasons. The aim of this study was to explore the theoretical and practical positions of English teachers in the use of first language in their classroom instruction. A total of 44 teachers of English at Karadeniz Technical University were involved in the study. The data were collected by administering a questionnaire containing 35 items and analyzed in SPSS 16.00. An in-depth interview with 12 participants was also used to gain more insight into the teachers' current classroom practices. Overall analysis indicates that a great majority of the teachers were found to take a practical and pragmatic position in the use of L1 instead of adhering to popular beliefs on this topic.
\end{abstract}

Key words: Mother tongue, L1, foreign language teaching, language teachers

\section{Öğretmen Uygulama ve PerspektifindenYabancı Dil Öğretiminde Anadil Kullanımı}

\begin{abstract}
Özet
Yabancı dil sınıflarında anadil kullanımından kaçınılması veya dahil edilmesi konusunda uzun süredir devam eden tartışmalar vardır. Anadilin ikinci dil öğrenimini kolaylaştırdığı veya öğrencilerin dil öğrenme sürecini zayıflatan bir etkiye sahip olduğu konusu, ikinci dil öğretiminde uzun yıllardır süregelen bir olgudur. Yabancı dil öğretiminde anadil kullanımını destekleyici veya da engelleyici rol oynadığını gösteren yeterli deneysel kanıtlar olmamasına rağmen, bazıları dil öğrenim sürecinde anadilin ikinci dil öğrenimini engellediği ya da öğrenim sürecine müdahale ettiği düşüncesinden dolayı ana dil kullanımından kaçınırken, bazıları da çeşitli sebeplerden dolayı farklı tavır almaktadırlar. Bu çalışmanın amacı, İngilizce öğretmenlerinin sınıf içinde anadilin kullanımıyla ilgili teorik tutumları ile uygulamadaki tavırlarını araştırmaktır. Çalışmaya Karadeniz Teknik Üniversitesinden 44 İngilizce öğretmeni katılmıştır. Veriler 35 maddeden oluşan anket aracılığıyla toplanıp ve SPSS 16.00 ile analiz edilmiştir. Ayrıca, mevcut sınıf uygulamalarıly ilgili derinlemesine bilgi edinmek için 12 katılımcıyla geniş kapsamlı görüşme yapılmıştır. Sonuç olarak, analizler öğretmenlerin bu konuyla ilgili geleneksel görüşlere bağlı kalmak yerine, ana dilin kullanımıyla ilgili pratik ve faydacı bir tavır aldıklarını göstermiştir.
\end{abstract}

Anahtar Sözcükler: Ana dil, L1, yabancı dil öğretimi, dil öğreticisi

*Asst.Prof.Dr., Karadeniz Technical University, Faculty of Letters, English Language and Literature, Trabzon, e-mail: naci@ktu.edu.tr 


\section{Introduction}

It appears that code-switching, which is described by Richards and Schmidt (2002) as "a change by a speaker (or writer) from one language or language variety to another one" (p. 81), has always been a matter of discussion. As Rolin-lanziti and Varshney (2008) remark, this debate dates back to 1980s when exclusivity attributed to target language for the first time with the Great Reform towards the end of the $19^{\text {th }}$ century was beginning to be questioned. This exclusivity was the result of the decreasing popularity of the GrammarTranslation Method, which allows the use of $L 1$, and the rising popularity of the Direct Method, which scarifies the use of target language (Sampson, 2011). Many figures from diverse contexts in fact favor an acceptable amount of first language, arguing that an optimal amount of $\mathrm{L} 1$ can be employed as an important pedagogical tool (Anton \&Dicamilla, 1999; Cook, 2001; Çelik, 2008; de la Colina\& Mayo, 2009; Gabrielatos, 2001; Huerta-Macias \&Kephart, 2009; Jingxia, 2010; Kahraman, 2009; Scott \& de la Fuente, 2008), though others argue against its use, citing a number of pitfalls (Sarıçoban, 2010; Turnbull, 2001). Kayaoğlu, Öztürk and DağAkbaş(2010) depict the latter mindset, stating:

\begin{abstract}
For a long time, many generations of EFL teachers adopted the principle to avoid the use of L1 in EFL classes as much as possible. Some have gone to the extent to say that they feel guilty and like they are betraying good language teaching practices when they have to use $\mathrm{L} 1$ in classroom. Moreover, the use of L1 was or has been associated with inadequacy and lack of expertise in language teaching. So it is to be avoided (p.401).
\end{abstract}

Although it can be claimed that there is a near-consensus among language teachers about maximizing the use of target language in classrooms for over 30 years (Scott \& de la Fuente, 2008) due to the popularity of second language acquisition research, one can observe a more tolerant attitude towards L1 exploitation nowadays (Gulzar, 2010). The argument of Carless (2008), for example, mirrors this ongoing debate in the field: the use of learners' first language can serve as "a humanistic and learner-centered strategy, with potential to support student learning, but at the same time involving a risk of failing to encourage TL practice and communication" ( $p$. 336). In order to gain insight into the issue from teachers' perspective, de la Campa and Nassaji (2009) conducted a study with two instructors teaching German at a university located in western Canada. Their findings show that both instructors frequently use L1 in their classes for pedagogical and social reasons, including translating, comparing and contrasting both languages, evaluating, giving instruction, explaining objectives of activities, eliciting students' ideas, voicing their personal ideas, reassuring that students have comprehended the topic, dealing with issues regarding classroom and administration, paraphrasing students' sentences, and making jokes. Both the experienced and novice instructors have positive attitudes towards the exploitation of L1 in that it enhances learning. On a personal level, the possible benefits of $\mathrm{L} 1$ are supported by the reflective report of Edstrom (2006) about her own classroom practices: giving grammar instructions, managing classroom, and compensating problems related to student comprehension. The argument of Ahmad and Jusoff (2009) also attributes a compensating role to $L 1$ for students with low language proficiency.

Another study, the focal concern of which is the functions of teachers' code-switching belongs to Gulzar (2010), who conducted a survey with 406 teachers in Pakistani EFL classrooms. The findings of the study indicate that teachers employ code-switching to their first language for eleven functions in a hierarchal order from the most frequently-cited to the lessreferred one: clarification, ease of expression, giving effective instruction, creating a sense of belonging, checking understanding, translation, socializing, emphasis, repetitive functions, topic shift, and linguistic competence. The author concludes that the use of L1 in bilingual education is legitimate, in the sense that a strict monolingual policy may lead to misperceptions, and as a consequence "educators, course developers, and teachers misunderstand language processes and cannot devise classroom strategies based on 
the appropriate use of languages" (p. 38). The study of Sampson (2011) on code-switching supports the findings of Gulzar (2010), in that his results show that first language has communicative functions in classrooms, including "expressing equivalence, discussing procedural concerns, floor holding, reiterating concepts, and forming group relationships" (p. 10).

In the same vein of thought, a study was conducted with four English teachers at a two after-school private language institutions in Cyprus by Copland and Neokleous (2011). Their transcriptions of the observed classes show that the teachers made use of $L 1$ for a total of eleven functions, including organizing the course, giving explanations, most notably grammar, giving instructions, asking and answering questions, reprimanding (Macaro, 2001), making jokes, praising, translating, using it as markers, giving hints and opinions to the students. However, the qualitative analysis of the interviews with the teachers indicates that all are critical of the use of Greek in language classes, even though they overuse it. Therefore, Copland and Neokleous conclude that there are contradictions between the actions and beliefs of the teachers because bilingual teachers have a sense of guilt when they teach L2 with L1.

Similarly, the attitude survey of McMillan and Rivers (2011) with 29 native-English speaker teachers at a Japanese university provides support for the positive role of $L 1$ in that it has the power to enhance cognition, communication, and social functions in language classrooms. Anton and Dicamilla (1999) buttress the point that the use of L1 helps learners to set up supportive collaboration among friends.

\section{Methodology}

The present study employed both quantitative and qualitative data gathering techniques with an aim to enhance the richness of the research findings. The quantitative data were gathered via a questionnaire. A total of 44 teachers of English at Karadeniz Technical University were involved in the study. The study was exploratory in nature on the issue, rather than doing generalization from the sample. The data were collected by administering the questionnaire, which was developed from the studies by Rolin-lanziti, J. and Varshney, R. (2008), Tang, J. (2002) and Kayaoğlu et al. (2010). Necessary modifications and adaptations were made to appeal to the Turkish context. After a pilot study, the generated questionnaire consisted of 35 items with a 5 point Likert-type scale. The data were analyzed in SPSS 16.00. The Cronbach alpha coefficient of the questionnaire was .80 . As Robson (1993) remarks, surveys conducted via questionnaires could "lend themselves well to be used in combination with other methods" (p. 227), and the quantitative data can be complemented with its qualitative counterpart to go deeper. Hence, an individual in-depth interview was also carried out to gain more insight into the teachers' current classroom practices. Twelve foreign language teachers from the School of Foreign Languages at Karadeniz Technical University voluntarily participated as interviewees. The semi-structured interview was designed to describe teachers' perspectives and practices on the use of L1 in EFL context. With this aim, teachers were asked mainly four questions which focused on the following: teachers' L1 use, practices and reasons in L1 use, where to use L1 and students' L1 use. All the interviews were audio-recorded and transcribed. Later, the qualitative data gathered from individual interviews were analyzed interpretively (Cohen, Manion,\& Morrison, 2007).

\section{Findings}

The current study mainly aimed to explore the teachers' perspectives and practices on the use of $\mathrm{L} 1$ in foreign language classes. As stated earlier, a 5-point, Likert scale type questionnaire containing 35 items was administered to 44 teachers from the School of Foreign Languages and SPSS 16.0 was used for data analysis. In response to the question about their use of Turkish in foreign language classes, $91 \%$ of the participants agreed on the use of Turkish and $68 \%$ of the teachers stated that Turkish should be used 'sometimes' (items $1,2)$. In the second part, teachers were given six items to express their perspectives on the students' use of Turkish (Table 1). From the findings, most of the teachers hold the view that the use of mother tongue is a facilitator in foreign language teaching. 
Table 1. Teachers' perspectives on the students' use of Turkish

\begin{tabular}{|c|c|c|c|c|c|c|c|c|c|c|}
\hline \multirow[t]{2}{*}{$\begin{array}{l}\text { Items } \\
\text { In FL Classroom, }\end{array}$} & \multicolumn{2}{|c|}{$\begin{array}{c}\text { Strongly } \\
\text { Agree }\end{array}$} & \multicolumn{2}{|c|}{ Agree } & \multicolumn{2}{|c|}{$\begin{array}{c}\text { Neither Agree } \\
\text { Nor Disagree }\end{array}$} & \multicolumn{2}{|c|}{ Disagree } & \multicolumn{2}{|c|}{$\begin{array}{l}\text { Strongly } \\
\text { Disagree }\end{array}$} \\
\hline & $\mathbf{N}$ & $\%$ & $\mathbf{N}$ & $\%$ & $\mathbf{N}$ & $\%$ & $\mathbf{N}$ & $\%$ & $\mathbf{N}$ & $\%$ \\
\hline 3. Ss learn English grammar easier in Turkish.* & 26 & 59,1 & 17 & 38,6 & & & & & 1 & 2,3 \\
\hline 4. Ss should use only English. & 3 & 6,8 & 11 & 25,0 & 6 & 13,6 & 18 & 40,9 & 5 & 11,4 \\
\hline \multicolumn{11}{|l|}{ 5. Ss should prefer books with English } \\
\hline explanation. & 6 & 13,6 & 7 & 15,9 & 6 & 13,6 & 19 & 43,2 & 5 & 11,4 \\
\hline 6. Ss should never use Turkish.* & 1 & 2,3 & 9 & 20,5 & 2 & 4,5 & 19 & 43,2 & 12 & 27,3 \\
\hline \multicolumn{11}{|l|}{ 7. Ss should prefer books with Turkish } \\
\hline explanation. & 9 & 20,5 & 16 & 36,4 & 11 & 25,0 & 4 & 9,1 & 4 & 9,1 \\
\hline 8. Ss should speak English in group works.* & 13 & 29,5 & 20 & 45,5 & 3 & 6,8 & 6 & 13,6 & 1 & 2,3 \\
\hline
\end{tabular}

In foreign language classrooms, overwhelmingly most of the teachers $(97.7 \%$ strongly agree and agree) had strong feeling about the idea that students learn English grammar easier when it is explained in Turkish. Only one of the teachers was observed to strongly disagree on the facilitating effect on grammar learning. It is remarkable to note that only $31 \%$ of the teachers agreed on the use of English only where $61.3 \%$ opposed to this idea. Similarly, only $23 \%$ of them shared the view that students should never use Turkish. Moreover, while 29.5\%of the teachers had the positive feeling on the use of books with English explanation, $55.6 \%$ were against this view. This finding is supported by the fact that most of the teachers supported the books with Turkish explanation. In addition, $75 \%$ of the teachers agreed that English should be used in students' group works.

Regarding the teachers' use of English in foreign language classes, $46 \%$ of the teachers agreed on both the use of Turkish in explaining English words and felt the need for the use of $L 1$ when students could not understand the meaning of a foreign word. However, $50 \%$ of the teachers highlighted that English should be used to explain unknown words. In addition, although $52 \%$ of the teachers stated that they preferred to use English in explaining grammar rules, $68 \%$ of them disagreed on the idea that teachers should use English only. More than half of the teachers (59\%) thought that the use of Turkish was a motivating factor in students' language learning and the teacher who used Turkish was more motivating than the teachers who used English (item 18). Therefore, they agreed that the use of Turkish made English learning easier and facilitated it better (items 15, 19, 23). As a result, most of the teachers (61.4\%) welcomed the idea of switching between English and Turkish while teaching English. Furthermore, majority of teachers (68.2\%) were in favor of using the mother tongue for describing instructions, exercises, tasks, etc. Furthermore, a great number of teachers $(75 \%)$ did not share the idea that the use of Turkish was a waste of time. It was found out that it would be beneficial to go over the topics in Turkish and it should not be considered as a waste of time (75\%, item 22 ).

The last section of the questionnaire sought to identify the teachers' purposes for using Turkish and for which skills they prefer to use it more. To this end, the following items (in Table 3) were asked to accomplish the objective. 
Table 2. Teachers' uses of Turkish in foreign language classes

\begin{tabular}{|c|c|c|c|c|c|c|c|c|c|c|}
\hline \multirow[b]{3}{*}{ Items } & \multirow{2}{*}{\multicolumn{2}{|c|}{$\begin{array}{c}\text { Strongly } \\
\text { Agree }\end{array}$}} & \multicolumn{6}{|c|}{ Neither } & \multirow{2}{*}{\multicolumn{2}{|c|}{$\begin{array}{l}\text { Strongly } \\
\text { Disagree }\end{array}$}} \\
\hline & & & \multicolumn{2}{|c|}{ Agree } & \multicolumn{2}{|c|}{$\begin{array}{l}\text { Agree Nor } \\
\text { Disagree }\end{array}$} & \multicolumn{2}{|c|}{ Disagree } & & \\
\hline & $\mathbf{N}$ & $\%$ & $\mathbf{N}$ & $\%$ & $\mathbf{N}$ & $\%$ & $\mathbf{N}$ & $\%$ & $\mathbf{N}$ & $\%$ \\
\hline 9. Turkish explanation for foreign words & 5 & 11,4 & 15 & 34,1 & 9 & 20,5 & 11 & 25,0 & 4 & 9,1 \\
\hline 10. Use of English to explain unknown words & 4 & 9,1 & 18 & 40,9 & 10 & 22,7 & 9 & 20,5 & 2 & 4,5 \\
\hline 11. Going over the topic in Turkish & 4 & 9,1 & 21 & 47,7 & 8 & 18,2 & 8 & 18,2 & 2 & 4,5 \\
\hline $\begin{array}{l}\text { 12. Use of Turkish for instructions, tasks, } \\
\text { exercises, etc. }\end{array}$ & 10 & 22,7 & 20 & 45,5 & 3 & 6,8 & 6 & 13,6 & 2 & 4,5 \\
\hline 13. Use of Turkish to explain unknown words & 4 & 9,1 & 16 & 36,4 & 7 & 15,9 & 11 & 25,0 & 3 & 6,8 \\
\hline $\begin{array}{l}\text { 14. Mother tongue is Turkish, should use } \\
\text { Turkish }\end{array}$ & 16 & 36,4 & 20 & 45,5 & 4 & 9,1 & 1 & 2,3 & 1 & 2,3 \\
\hline $\begin{array}{l}\text { 15. Use of Turkish makes English learning } \\
\text { easy* }\end{array}$ & 11 & 25,0 & 18 & 40,9 & 6 & 13,6 & 5 & 11,4 & 3 & 6,8 \\
\hline 16. Prefer to explain grammar rules in English & 9 & 20,5 & 14 & 31,8 & 2 & 4,5 & 10 & 22,7 & 6 & 13,6 \\
\hline 17. Ts should use English only & 2 & 4,5 & 4 & 9,1 & 7 & 15,9 & 17 & 38,6 & 3 & 29,5 \\
\hline $\begin{array}{l}\text { 18. Ts using Turkish is more motivating than } \\
\text { Ts using English* }\end{array}$ & 5 & 11,4 & 16 & 36,4 & 9 & 20,5 & 8 & 18,2 & 4 & 9,1 \\
\hline $\begin{array}{l}\text { 19. Use of Turkish makes English learning } \\
\text { difficult }\end{array}$ & 4 & 9,1 & 6 & 13,6 & 6 & 13,6 & 18 & 40,9 & 9 & 20,5 \\
\hline $\begin{array}{l}\text { 20. Switching between English and Turkish } \\
\text { is confusing* }\end{array}$ & 1 & 2,3 & 3 & 6,8 & 9 & 20,5 & 18 & 40,9 & 2 & 27,3 \\
\hline 21. Use of Turkish is a waste of time. & 4 & 9,1 & 2 & 4,5 & 4 & 9,1 & 20 & 45,5 & 3 & 29,5 \\
\hline 22. Use of Turkish is a motivating factor. & 8 & 18,2 & 18 & 40,9 & 7 & 15,9 & 5 & 11,4 & 5 & 11,4 \\
\hline $\begin{array}{l}\text { 23. Use of Turkish facilitates English learning } \\
\text { better.* }\end{array}$ & 14 & 31,8 & 16 & 36,4 & 6 & 13,6 & 4 & 9,1 & 2 & 4,5 \\
\hline
\end{tabular}

It was observed that $43 \%$ of the teachers 'sometimes' used Turkish for giving the meanings of new words and $39 \%$ of them used it 'often' for explaining complex sentence structures and difficult concepts. It can be interpreted that teachers 'often' prefer to use L1 to save time (36\%) by describing or clarifying the points which might create problems in their courses. Additionally, the study revealed that teachers 'often' used Turkish to decrease students' anxiety level and 'sometimes' (36 \%) to increase students' motivation.

It was observed that among all skills, Turkish was 'often' (50\%) used in teaching grammar. Grammar was followed by writing course (36 $\%)$. It was clearly indicated that L1 'rarely' (27 $\%)$ used for listening and 'never' (34\%) for speaking; however, one striking point was that some of the teachers pointed out that Turkish should be used in speaking course 'sometimes' (27\%). Nearly half of the teachers 
Table 3. The purposes of using Turkish

\begin{tabular}{lcccccccccc}
\hline & \multicolumn{2}{c}{ Always } & \multicolumn{3}{c}{ Often } & \multicolumn{3}{c}{ Sometimes } & \multicolumn{3}{c}{ Rarely } & \multicolumn{2}{c}{ Never } \\
Items & $\mathbf{N}$ & $\%$ & $\mathbf{N}$ & $\%$ & $\mathbf{N}$ & $\%$ & $\mathbf{N}$ & $\%$ & $\mathbf{N}$ & $\%$ \\
\hline 24.For new words* & 3 & 6,8 & 11 & 25,0 & 19 & 43,2 & 5 & 11,4 & 4 & 9,1 \\
25. For complex sentence structures & 12 & 27,3 & 17 & 38,6 & 12 & 27,3 & 1 & 2,3 & 1 & 2,3 \\
26. For difficult concepts* & 14 & 31,8 & 17 & 38,6 & 10 & 22,7 & 1 & 2,3 & 1 & 2,3 \\
27. For general information on course & 8 & 18,2 & 15 & 34,1 & 8 & 18,2 & 5 & 11,4 & 6 & 13,6 \\
28. To increase motivation & 5 & 11,4 & 10 & 22,7 & 16 & 36,4 & 9 & 20,5 & 3 & 6,8 \\
29. To avoid waste of time & 12 & 27,3 & 16 & 36,4 & 11 & 25,0 & 3 & 6,8 & & \\
30. To decrease anxiety* & 11 & 25,0 & 15 & 34,1 & 13 & 29,5 & 4 & 9,1 & & \\
31. For grammar course* & 10 & 22,7 & 22 & 50,0 & 8 & 18,2 & 1 & 2,3 & 1 & 2,3 \\
32. For reading course* & 2 & 4,5 & 5 & 11,4 & 20 & 45,5 & 10 & 22,7 & 5 & 11,4 \\
33. For writing course & 8 & 18,2 & 16 & 36,4 & 12 & 27,3 & 4 & 9,1 & 2 & 4,5 \\
34. For listening course & 3 & 6,8 & 6 & 13,6 & 11 & 25,0 & 12 & 27,3 & 11 & 25,0 \\
35. For speaking course* & 1 & 2,3 & 4 & 9,1 & 12 & 27,3 & 11 & 25,0 & 15 & 34,1 \\
\hline
\end{tabular}

(46 \%) reported that they might use L1 'sometimes' in reading courses.

In summary, itseems that the teachersgenerally had a balanced and eclectic approach to the use of mother tongue in foreign language teaching. Instead of adhering to a certain theoretical foundation most appear to take a practical and pedagogical position in the use of mother tongue in teaching the target language.

\section{Interview Results}

The data obtained from interviews was classified into categories organized by the interview questions. The responses given to each question were analyzed and discussed under each question. Certain quotations were used to represent participants' genuine thoughts. The interview reports not only provided more insight into the matter but also served to validatethe results obtained from the quantitative data.

\section{Teachers' L1 Use}

The first question was about teachers' perspectives on the use of $L 1$; whether they were in favor of using L1 or completely opposed to use it. The interviews showed that interviewees agreed on the necessity of the teachers' L1 use in foreign language classrooms in general. This is in line with the questionnaire results that more than half of the teachers (59\%) thought that the use of Turkish was a motivating factor in students' language learning and the teacher who used Turkish was more motivating than the teachers who used only English (item 18 in Table 2). However, most of them insisted on the view that the use of L1 could vary according to skills and students' levels. All of the teachers were strict about the use of target language in speaking and listening courses because they believed that students should be exposed to target language use. The more students are exposed to the target language, the more successful they become. The same stress on avoiding L1 in speaking courses was observed in the quantitative data analysis that only 11.4 $\%$ (combining "always" and "often in item 35) appeared to have positive feeling about the use of L1 in conversation classes. The same pattern was observed for listening course as indicated in Table 3. On the other hand, all of the teachers asserted that they use L1 in their grammar courses and especially in beginner levels and they highly recommended colleagues to use their mother tongue. One of the interviewees stated that there is no need to insist on the use of $L 2$ if the students are in the beginner level. This also provides 
further evidence for the fact that a substantial number of teachers were observed to use L1 in order to decrease students' anxiety level as indicated in Table 3. It is obvious that this might demotivate students from the very first minutes of the course, because students having no background in L2 might feel anxious and this might put the students on the fast track to failure. Therefore, foreign language teachers should consider the sideeffect of "the ideology of using L2 completely" resulting in psychological pressure on the students. Another striking point is the amount of L1 use. Teachers generally stated the importance of the amount of L1 use in EFL classroom. Teachers believe that they are the ones who are responsible for balancing the L1 use. One of the interviewees pointed out that the teachers should decide where, when and how much to use L1:

I don't always use L1 during
the whole class but I can simply
summarize the topics using L1,
especially in the beginning level
students. But of course, L1 is not
used so much in pre-intermediate
and intermediate classes.
Particularly, there is no need to
use $L 1$ in intermediate classes.
Yet, this is something which the
teacher decides. The teacher can
see the level of class, their level of
comprehension on students' faces.
As for grammar classes, teacher
can improvise in the class but $L 1$
can rarely be for listening, reading
and speaking classes used. Yet, I
think using L1 is unnecessary in
speaking and listening classes.

\section{Practices and Reasons in L1 Use}

The second question was about teachers' practices and reasons in using L1. They were asked why and where they used L1 in their classrooms and in which cases they felt the need of L1 and how they justified their L1 use or vice versa. The interviewees asserted that L1 strengthened students' skills and provided teachers with some advantages such as simplification of difficult topics. Some of the teachers highlighted that L1 use supported classroom management and warmed up the relationship between the students and teachers; therefore, they were in favor of using mother tongue. Moreover, some of the teachers expressed that L1 should be used to clarify topics. Two of the interviewees claimed that L1 made students feel more comfortable in EFL setting and helped them to decrease their anxiety levels or to demolish anxiety barriers, validating the responses given to the items $25,26,28$, and 30 in the questionnaire. Additionally, some of the teachers put forward that L1 use facilitated foreign language learning and made it more efficient and saved time. One of the interviewees stated:

... I think $L 1$ use is more effective
in grammar courses of beginner
classes; that is to say, you may not
be able to teach a grammatical rule
after many hours of things such as
acting, demonstrating and miming
as in the Direct Method. However,
when you use $L 1$, it will save a lot of
energy and time.

Another point is that some of the teachers preferred to use L1 in order to be certain whether students understand or learn the topic. One of the teachers voiced:

In fact, when they use their
first language, I understand
better whether they have really
comprehended something. For this
reason, I am in favor of using $L 1$.

\section{Where to use L1}

Four of the interviewees pointed out that L1 should be used while giving instructions to their students in classrooms or in oral/written exams. This result is in line with the responses given to the item 12 (in Table 2) concerning the use of Turkish for instructions, tasks, and exercises in the questionnaire. They stated that both teachers themselves and students wanted to be sure that the whole message was transferred to the students properly. Moreover, some of the teachers specified that L1 should be used while describing similarities and differences between tenses of target language and also between target and first language. Some of the teachers claimed that L1 should be used in explaining the topics, 
especially grammatical items, units or rules with the aim of clarifying and making them understandable for students, validating the result that $96.7 \%$ of the teachers held the view that students learned English grammar easier when explained in Turkish (in the item 3 in Table 1, combining strongly agree and agree).In addition, some of the teachers stated that they sometimes brought additional materials such as idioms and proverbs to the classroom and in order to explain and give their equivalents, teachers used L1.

\section{Students' L1 Use}

The third question was about students' L1 use. Nearly all of the interviewees agreed on the idea that students can use their first language in language classroom, though it might differ according to courses and levels. Some of the teachers supported students' use of L1 in beginner classes since those students did not have a background target language background so students might sit in silence for hours and hours without uttering any sentence or even words. A very similar pattern was observed in teachers' responses to the item 23 that $96.7 \%$ of the teachers held the view that the use of Turkish facilitated English learning better. Therefore, students' L1 use should be welcomed in the beginner classes but this does not mean that students can use their mother tongue in all courses. One of the teachers stated:

$$
\begin{aligned}
& \text { If I were teaching speaking, I } \\
& \text { wouldn't find it appropriate if } \\
& \text { students reply to me in their first } \\
& \text { language. But in grammar classes, } \\
& \text { we usually discuss some structures } \\
& \text { so I do not really care whether they } \\
& \text { use L1 or L2. }
\end{aligned}
$$

It is understood that there is a consensus among the teachers on the students' use of L1 in grammar courses, especially for asking questions. Most of the teachers believed that students had language anxiety and teachers should allow their students to ask questions in their mother tongue in order to make students calm and relax. One of the teachers expressed his ideas with the following sentences:
At the beginning level, students already have high anxiety level and they tend to be indifferent in asking questions because of the lack of $L 2$ knowledge. They want to ask questions but they can't do it in English.

In contrast with the above statement, one of the teachers put forward that the most important thing is to teach something:

\section{All in all, responding to a question in \\ Turkish indicates that the question asked in English is understood by the students. In that sense, I don't consider it as a big problem.}

It can be inferred that sometimes students' use of their mother tongue might indicate that they can comprehend something presented to them, but in this case, the teacher should look into the reasons why the students do not respond in English--whether they have difficulty in structuring sentences or are afraid of speaking in the target language, etc.. At the end of the interviews, it was observed that only one of the teachers was strict about the students' use of L1 and stated that "students should use L2 even in asking questions".

\section{Perspective, Experience and Change}

The fourth question sought to explore what teachers' perspectives on foreign language teaching from the very first days of teaching were and what changes, if there are any, after their teaching experiences were observed. It was interpreted from the interviews that all of the teachers started to teach with the idea of using only the target language. However, after experiencing many years of teaching, they realized that there was no need to insist on using L2. Here are some of the statements reflecting the changes in teachers' perspectives towards using L1 as they got more experienced:

There is a very important change. I thought that I would never use mother tongue in the first year of my profession. However, I recognized that I needed to use $L 1$ after teaching some courses and 
seeing the proficiency levels of the students. At first, I was in favor of using only English because I used to think that as the target language was English, students could learn through listening to English. However, I observed that students got bored quickly and could not bear uncertainty when they didn't understand anything. Therefore, I partly support the use of L1. I am against $L 2$ use only.

The commonly shared process through which most teachers appeared to have gone was also similarly reflected in the responses given to the item 20 that most teachers felt at ease switching between English and Turkish.

\section{Discussion}

Although there is still controversy as to whether L1 should be allowed in foreign language classrooms, its pragmatic and practical benefits could not be overlooked. When the findings of the present study are looked through, it could be seen that teachers tend to assign distinctive roles to L1 in the foreign language learning setting in KTU. Most of the participants are seen to hold positive attitudes towards the employment of Turkish while teaching English in the sense that this code-switching could be of help to both parties, namely teachers and students.

The results of quantitative and qualitative data reveal that teachers take a positive attitude toward the integration of $\mathrm{L} 1$ into their classes, remarking that Turkish facilitates one's own teaching, particularly grammar and vocabulary at early stages, giving comprehensible instructions, creating a supportive classroom environment. Most of the participants were seen to hold the view that Turkish is an auxiliary tool for language classes, arguing that its use changes according to language skills and students' levels. Particularly grammar teaching at early stages necessitates the integration of $\mathrm{L} 1$ in case some complex points may not be fully comprehended by students, which may lead to the formation of anxiety barriers to language learning. These finding are in line with the findings of a great many scholars in the field, including de la Campa and Nassaji (2009), Gulzar (2010), Copland and Neokleous (2011), and so forth. The findings from the interviews and the questionnaires of the present study related to the idea that the use of L1 serves students well, especially beginner students, support the findings of Kim and Petraki (2009), who found that the use of $\mathrm{L} 1$ turned the reading and writing tasks into manageable pieces of language works for students at beginner levels. There was almost consensus among the participants that the use of $\mathrm{L} 1$ for the teaching of grammar, vocabulary, reading, and writing is indispensable while its employment for speaking and listening courses is not tolerable. These findings are in line with the results of the studies, such as Giannikas (2011), Gulzar (2010), and so forth, who found that a systematic employment of L1 in foreign language classes may overcome a great many problems from course content to affective dimension. Lastly, the findings related to teachers' profile of using L1 are worth presenting in that they demonstrate a movement from holding an English-only policy to an acceptable and non-random L1 use on an L1-L2 use continuum.

\section{Conclusion}

The use of mother tongue has been a taboo subject for a long time because the predominant use of the target language has long been considered an important principle of second language (L2) learning. According to this orthodoxy, the teacher appears to be the primary source of language input and therefore responsible for maximizing its use in the classroom. So, avoidance of the L1 is/ was associated with good teaching during the heydays of Direct and Audio-lingual methods. The judgment on a foreign language teacher's quality often is related to his/her ability to do the whole class in the target language. The related literature shows that recently the idea of its systematic and acceptable employment has been frequently voiced by a number of figures, arguing that its nonrandom integration into language instruction may lead to an array of benefits ranging from academic to affective domains. The findings of the present study have demonstrated that teachers are aware of its possible gains, and it is likely that the more experienced they get 
in their profession, the more inclined they become to employ it systematically in their language instruction.

The study is seen to provide support for some of the previously-conducted research both around the world and in Turkey, but still it does not tell the entire story as it aimed at exploring the practices and perceptions of a limited number of university teachers. However, the consensus among the participants and their experiences may give the hint that its systematic use in the realm of language teaching could serve as an auxiliary tool for not only teachers but also students. In pedagogic terms, it is ironic to teach a foreign language without reference to the students' mother tongue and, by extension, their mother culture. The decision to use the L1 reflects a variety of factors and multiple goals. The questions of "when and where the L1 should be used, how much it is to be used and whether the use of L1 is a hindrance or a help in L2 acquisition" cannot adequately be answered without reference to sociological, psychological, pedagogic and linguistic dimensions of the issue. The quantity of L1 use and the way it is used is inseparably linked to the underlying function or purpose of the program and the teacher. Language acquisition may not be only objective. In some cases extensive L1 use may be a better pedagogic or linguistic choice. What teachers need to know is that they should not tend to allow its use all the time as it may turn to an unbreakable habit interfering with the target language. It is wise for them to assign a kind of "go-between role" which is justifiable on the grounds of costs and benefits. Being in a better position in all cases, teachers, with their own pedagogic values and justification, should critically analyze their own context and make well-informed, realistic decisions about the use of the L1 instead of half-heartedly or blindly adhering to an assumption.

\section{REFERENCES}

Ahmad, B. H., \& Jusoff, K. (2009). Teachers' codeswitching in classroom instructions for low English proficient learners. English Language Teaching, 2(2), 49-55.

Anton, M., \& Dicamilla, F. J. (1999). Socio-cognitive functions of collaborative interaction in the L2 classroom. The Modern Language Journal, 83, 233-247.

Carless, D. (2008). Student use of the mother tongue in the task-based classroom. ELT Journal, 62(4), 331-338. doi: 10.1093/elt/ ccm090.

Cohen, L., Manion, L., \& Morrison, K. (2007).Research methods in education (6th.ed.). New York, NY: Routledge.

Cook, V. (2001). Using the first language in the classroom. The Canadian Modern Language Review, 57(3), 402-423.

Copland, F., \& Neokleous, G. (2011). L1 to teach L2: Complexities and contradictions. ELT Journal, 65(3), 270-280. doi: 10.1093/elt/ ccq047.

Çelik, S. (2008). Opening the door: An examination of mother tongue use in foreign language classrooms [Yabancı dil sınıflarında ana dil kullanımının incelenmesi]. acettepeÜniver sitesiEğitimFakültesiDergisi (H. U. Journal of Education), 34, 75-85.

De la Campa, J. C., \& Nassaji, H. (2009). The amount, purpose, and reasons for using L1 in L2 classrooms. Foreign Language Annals, 42(4), 742-759.

De la Colina, A. A., \& Mayo, M. D. P. G. (2009).Oral interaction in task-based EFL learning: The use of $\mathrm{L} 1$ as a cognitive tool. IRAL, 47, 325345. doi: 10.151/iral.2009.014.

Edstrom, A. (2006). L1 use in the L2 classroom: One teacher's self-evaluation. The Canadian Modern Language Review, 63(2), 275-292.

Gabrielatos, C. (2001). L1 use in ELT: Not a skeleton, but a bone of contention. TESOL Greece Newsletter, 70, 6-9.

Giannikas, C. N. (2011). L1 in English language learning: A research study in a Greek regional context. International Journal of Applied Linguistics, 21(3), 319-339.

Gulzar, M. A. (2010). Code-switching: Awareness about its utility in bilingual classrooms. Bulletin of Education and Research, 32(2), 23-44. 
Huerta-Macias, A., \& Kephart, K. (2009). Reflections on native language use in adult ESL classrooms. Adult Basic Education and Literacy Journal, 3(2), 82-96.

Jingxia, L. (2010). Teachers' code-switching to the L1 in EFL classroom. The Open Applied Linguistics Journal, 3, 10-23.

Kahraman, A. (2009). The role of the mother tongue in fostering affective factors in ELT classrooms.Journal of English as an International Language, 5, 107-128.

Kayaoğlu, M. N., Öztürk, Z., \& DağAkbaş, R. (2010). L1 use in EFL classroom: The attitudes of students. Dinçay, K., Erten, İ. H., ZehirTopkaya, E., \&Yavuz, A. (Eds.) The 6th International ELT Research Conference Proceedings: Current trends in SLA research and language teaching (pp. 401-407). Selçuk, İzmir: ÇanakkaleOnsekiz Mart University.

Kim, Y., \& Petraki, E. (2009). Students' and teachers' use of and attitudes to L1 in the EFL classrooms. Asian EFL Journal, 11(4), 58-89.

Macaro, E. (2001). Analysing student teachers' codeswitching in foreign language classrooms: Theories and decision making. Modern Language Journal, 85, 531-548.

McMillan, B., \& Rivers, D. J. (2011). The practice of policy: Teacher attitudes toward "English only". System, 39, 251-263. doi: 10.1016/j. system.2011.04.011.
Robson, C. (1993). Real world research: A resource for social scientists and practitionerresearchers. Oxford, UK: Basil Blackwell Inc.

Richards, J. C., \& Schmidt, R. (2002).Dictionary of language teaching and applied linguistics (3rd ed.). Essex, England: Pearson Education Limited.

Rolin-lanziti, J., \& Varshney, R. (2008). Students' views regarding the use of the first language: An exploratory study in a tertiary context maximizing target language use. The Canadian Modern Language Review, 65(2), 249-273. doi:10.3138/cmlr.65.2.249.

Sampson, A. (2011). Learner code-switching versus English only.ELT Journal, 3, 1-11. doi: 10.1093/elt/ccr067

Sarıçoban, A. (2010). Should native languages be allowed in foreign language classes? Eurasian Journal of Educational Research, 38, 164-178.

Scott, V., \& de la Fuente, M. J. (2008). What's the problem? L2 learners' use of the L1 during consciousness-raising, form-focused tasks. The Modern Language Journal, 92(i), 100-113.

Tang, J. (2002). Using L1 in the English Classroom. English Teaching Forum,40(1), 36-43.

Turnbull, M. (2001). There is a role for the L1 in second and foreign language teaching, but... The Canadian Modern Language Review, 57(4), 531-540. 